\title{
Performance of tractor operated two row sugarcane cutter planter for sugarcane planting in Andhra Pradesh State, India
}

\section{P. Sreedevi and P.V.K. Jagannadha Rao}

Received : 19.07.2018; Revised : 23.08.2018; Accepted : 10.09.2018

See end of the Paper for authors' affiliation

Correspondence to :

P. Sreedevi

Regional Agricultural Research

Station (A.N.G.R.A.U.)

Anakapalle, Hyderabad

(Telangana) India

Email : sreedevinasa@gmail.

com
- ABSTRACT : Sugarcane is an important agro-industrial crop requiring more labour force for planting. Presently, in traditional cultivation of sugarcane, all the operations are being done manually or semi mechanized stage, 60 per cent of the cost incurred towards labour charges. Sugarcane planting involves cutting of setts, opening of furrows, placing the setts in furrows and covering the setts with soil which is tedious, time consuming process and labour intensive. Introduction of mechanized planter will perform all these operations simultaneously and reduce dependency on labour and complete the farm operations in time. A field experiment was conducted at Regional Agricultural Research Station, Anakapalle, Andhra Pradesh to evaluate the performance of tractor mounted two row sugarcane cutter planter. The field capacity of the equipment was found to be $0.16 \mathrm{ha} / \mathrm{h}$. The biometric parameters viz., diameter of the cane, height of the cane and yield of mechanically planted sugarcane was on par with the manually planted sugarcane where as single cane weight and root spread area were found to be significantly different $(p<0.05)$. Similarly, the juice quality of mechanically planted sugarcane in terms of degree Brix, sucrose per cent was on par with conventionally planted sugarcane. Economic analysis revealed that cost of planting with sugarcane cutter planter was Rs.15,400 per ha as against Rs. 6750 with traditional method of planting. The saving in labour cost, seed quantity and planting time with sugarcane cutter planter were to the tune of 51 per cent, 68 per cent and 58 per cent, respectively compared to conventional method of planting.

- KEY WORDS : Sugarcane cutter planter, Traditional planting, Labour cost

- HOW TO CITE THIS PAPER : Sreedevi, P. and Rao, P.V.K. Jagannadha (2018). Performance of tractor operated two row sugarcane cutter planter for sugarcane planting in Andhra Pradesh State, India. Internat. J. Agric. Engg., 11(2) : 353-358, DOI: 10.15740/HAS/IJAE/11.2/353-358. Copyright@2018: Hind Agri-Horticultural Society. 